\title{
E-viittaamisen ihanuus ja kurjuus
}

\author{
Juha Hakala \\ Kansalliskirjasto \\ juha.hakala@helsinki.fi \\ http://orcid.org/0000-0003-1067-5020
}

Asiasanat: viitteet; viiteanalyysi; bibliometriikka; pitkäaikaissäilytys; tunnisteet

Alussa oli nimi-vuosijärjestelmä, myös Harvardina tunnettu. Sitten saimme numeroviitejärjestelmän, alaviitejärjestelmän, ja suuren joukon erilaisia tieteenala- ja aineistokohtaisia versioita näistä perusratkaisuista. Ja kun vielä tieteelliset lehdet ovat julkistaneet omia ohjeistuksiaan, on päädytty siihen että erilaisia viittausohjeistoja on tuhansittain. Citation Style Language tukee yli 8000 erilaista tyyliä ${ }^{1}$.

Tämä viittausmenetelmien rikkaus näkyy myös suomalaisten korkeakoulujen julkaisemissa tieteellisen viittaamisen ohjeistoissa. Ne saattavat olla yleisiä ${ }^{2}$, tieteenala${ }^{3,4}$ tai aineistokohtaisia ${ }^{5}$. Elektronisiin aineistoihinkin viittaamista on ohjeistettu jo 9o-luvulla (Heinisuo \& Ekholm, 1997), mutta uudenlaisten e-aineistojen (sosiaalinen media) vuoksi vanhojen ohjeiden sovellettavuus on rajallinen. 20 vuodessa olemme myös oppineet kantapään kautta paljon lisää siitä, mitkä e-aineistoihin viittaamisen haasteet ovat.

\footnotetext{
1 http://citationstyles.org/

2 http://libguides.aalto.fi/tieteellinen_viittaaminen

3 https://www.avoin.helsinki.fi/oppimateriaalit/kasvatustieteet/essee_ohjeet.htm

4 http://www.uta.fi/yky/oppiaineet/sosiaalipolitiikka/kaytannot/viittausohjeet.html

5 http://wWw.fsd.uta.fi/fi/aineistot/jatkokaytto/viittaaminen.html

Artikkeli on lisensoitu Creative Commons Nimeä-EiKaupallinen-JaaSamoin 4.o Kansainvälinen -lisenssillä

Pysyvä osoite: https://doi.org/10.23978/inf.65190
} 
Viittaamalla osoitetaan tietojen alkuperä ja annetaan lukijalle mahdollisuus tarkistaa, että niitä on käytetty oikein. Lähdeviitteen avulla lukija voi löytää viitatun julkaisun ja hankkia sen itselleen. Viittauksien tai niitten puutteen avulla on myös kyetty todistamaan tieteellinen vilppi - tunnettuina esimerkkeinä Jari Vilénin pro gradu, jonka tekstistä suuri osa on kopioitu lähdettä mainitsematta ${ }^{6}$ ja Carl Öhmanin lisensiaatintyön keksityt lähteet ${ }^{7}$.

\section{E-aineistoihin viittaamisen haasteista}

Elektronisiin aineistoihin viittaaminen ei periaatteessa poikkea perinteisiin aineistoihin viittaamisesta. Molemmissa tapauksissa viitatusta resurssista on annettava riittävät bibliografiset tiedot, kuten tekijä, nimeke, tunniste, julkaisija, julkaisuaika ja -paikka. Mutta Internet-verkossa saatavilla olevasta julkaisusta on kerrottava myös se, miten siihen pääsee käsiksi. Tähän on kaksi perusratkaisua: URL-osoitteen tai pysyvään tunnukseen perustuvan linkin antaminen.

Perinteisellä aineistolla tehty tieteellinen vilppi saattaa tulla ilmi vasta vuosikymmenien päästä. Carl Öhmanin lisensiaatintyössä (1961) siteerattuja Strindbergin kirjeitä ei ole löydetty arkistoista eikä Öhmanin itsensä hallusta. Mutta jos lähteenä käytetty dokumentti katoaa verkosta, vilpin osoittaminen jälkikäteen on mahdotonta. Jos merkittävä osa verkosta poimituista lähteistä häviää tai muuttuu jo muutamassa vuodessa, on tilanne tutkimuksen kannalta vähintään kiusallinen, ellei kriittinen.

E-viittaamisen kannalta oleellisia kysymyksiä ovat ainakin seuraavat:

- Mihin e-aineistoon voi ylipäätään viitata

- Ovatko URL-osoitteet luotettavia?

- Voidaanko URL-osoitteiden sijasta käyttää jotain muuta, ja miten luotettavia nämä korvaavat vaihtoehdot ovat?

- Osaavatko tutkijat käyttää näitä korvaavia vaihtoehtoja?

Viittauskäytännöt ovat liberalisoitumassa siten, että melkein mitä tahansa Internetistä löytyvää aineistoa voi käyttää ja käytetään lähteenä. Jos on tarve viitata esimerkiksi twiitteihin tai Facebookiin, American Psychological Associationin viittausohjeisto kertoo, miten sen voi tehdä ${ }^{8}$.

\footnotetext{
6 http://www.oulu.fi/dokumentit/Vilen-selvitys.pdf

7 https://fi.wikipedia.org/wiki/Carl_öhman

8 http://blog.apastyle.org/apastyle/2013/10/how-to-cite-social-media-in-apa-

style.html
} 
Tutkimuksen kannalta haasteellista on, että vaikka e-aineistoja käytetään yhä enemmän lähteinä, niiden osoitteisiin ei voi luottaa. Tämän joutuu moni Webin käyttäjä toteamaan lähes päivittäin, mutta asiasta on saatavilla myös tutkimustietoa.

Herbert Van de Sompel on julkaissut tutkimusryhmineen kaksi tutkimusta (Jones ym., 2016; Klein ym., 2014), joissa on selvitetty URL-osoitteiden viitemätää toisaalta linkkimädän, toisaalta sisältönyrjähdyksen näkökulmista. Edellinen tarkoittaa viitatun julkaisun katoamista (virhe 404), jälkimmäinen sitä käyttäjän kannalta vaikeasti todennettavaa tilannetta, että julkaisun sisältö on oleellisesti muuttunut.

Tutkimusaineistona oli miljoona e-viitettä 3.5 miljoonasta luonnontieteellisestä, lääketieteellisestä tai tekniikan alan artikkelista, jotka oli julkaistu vuosina 19972012. Aineisto kerättiin kolmesta korpuksesta (arXiv, Elsievier, PubMed Central). Tutkimushankkeen ensimmäisessä vaiheessa (Klein ym., 2014) havaittiin, että joka viidennessä artikkelissa oli yksi tai useampia kuolleita linkkejä. Sisältönyrjähdykseen keskittyneessä kakkosvaiheessa (Jones ym., 2016) todettiin, että toimivista linkeistä huomattava osa johdatti lukijan merkittävästi muuttuneeseen lähteeseen.

Voimme perustellusti vetää näistä tutkimuksista sen johtopäätöksen, että URLosoitteiden käyttöä viittaamisessa tulisi välttää, jos se on mahdollista. Jyväskylän yliopiston viittausohjeessa (Jyväskylän yliopiston kirjasto, 2017) asiaan on otettu vielä jyrkempi kanta:

Verkkosivujen pysyviä yleisesti tunnettuja osoitteita ovat mm. DOI- ja URN -osoitteet ja Permalink:it. Jos et löydä mitään tunnistetietoja sivustosta, se ei ole lähde, jota sinun kannattaa ylipäätänsä käyttää tieteellisessä kirjoittamisessa.

Sinänsä kannatettava ohje, mutta käytännössä sitä on vaikea noudattaa. Esimerkiksi tätä artikkelia - joka ei toki ole mikään tieteellinen teksti - ei olisi ollut mahdollista kirjoittaa ilman sivustoja, joilla ei ole pysyviä osoitteita - kuten sivu, jolta yllä mainittu lainaus on peräisin.

Tieteellisten julkaisujen käyttäjän kannalta ongelmaa pahentaa se, että vaikka viitattavalla julkaisulla olisi pysyvä tunnus, viitteessä käytetään julkaisun URLosoitetta. Herbert Van de Sompel ja kumppanit (2016) löysivät tutkimusaineistostaan yli puoli miljoonaa viitettä, joissa olisi voinut / pitänyt käyttää DOI-tunnusta. Mitään selkeää yksittäistä syytä DOI-aversiolle tutkimuksessa ei kyetty osoittamaan (emt.). Joka tapauksessa vastaus viimeiseen yllä esitetyistä kysymyksistä on osin kielteinen - ainakaan kaikki tutkijat eivät ymmärrä, miten tärkeää on käyttää pysyviä tunnuksia ja permalinkkejä. 


\section{Onko suutarin lapsella huonot kengät?}

Ovatko kotimaisten kirjastoalan lehtien kuten Informaatiotutkimuksen ${ }^{9}$ tai Signu$\min ^{10}$ artikkeleiden lähdeviitteiden URL-osoitteet kestäneet aikaa Van de Sompelin tutkimusaineistoa paremmin? Selvitin asiaa Signumin osalta otoksella vuosina 2005-2006 julkaistuista artikkeleista. Näin vanhassa aineistossa e-viitteitä on vielä varsin niukasti, mutta tulokset ovat kuitenkin suuntaa antavia.

Kaisa Sinikaran artikkelissa "Arviointi, laatu ja vaikuttavuus kehittämisessä tapausesimerkkinä Helsingin yliopiston kirjastolaitos" lähteenä olleita, vuonna 2000 julkaistuja Helsingin yliopiston kirjastojen arviointiprojektin loppuraporttia ja kansainvälisen arviointipaneelin raporttia ei enää löydy elektronisena julkaisuna alkuperäisestä osoitteesta. Internet Archivessa molemmat raportit ovat edelleen tallessa, mutta esimerkiksi loppuraportti on Internet Archiven sivuston mukaan hävinnyt tai siirtynyt toiseen osoitteeseen jo $2004^{11}$.

Anne Lehdon artikkelissa "Informaatiolukutaidon opintosuunnitelmalla lisää laatua ja vertailtavuutta tutkintoihin" on neljä elektronista lähdettä, joista vain yksi on edelleen verkossa, mutta kaikki kadonneet lähteet ovat edelleen Internet Archivesta haettavissa.

Terttu Kortelaisen ja Kristiina Miilukankaan "FinELibin aineiston näkyvyys lähdeanalyysin avulla" -artikkelin linkit FinELib-palveluun sekä FinELibiä kuvaavaan Tietolinja-lehden artikkeliin eivät enää toimi. Linkki Ulrich’s Periodicals Directoryyn ohjautuu palvelun nykyiseen osoitteeseen, mutta verkkoarkistoon tallentunut 12 vuoden takainen kopio järjestelmän kotisivusta osoittaa, että palvelun käyttöliittymä ja sisältö ovat muuttuneet perusteellisesti.

Reeta Elorannan artikkelissa "Kirjastot 2015 - Informaatiotutkimuksen tulevaisuupaja [sic] luotaa tulevaisuuteen" on URL-osoitteet Tampereen yliopiston Informaatiotutkimuksen laitoksen sekä RistiinRastiin-projektin kotisivuille. Molemmat linkit ovat kuolleet, mutta sivustot löytyvät Internet Archivesta. Minna Kaukosen Mikaela-verkkopalvelun kuvaus ("Mikaela-verkkopalvelu tuo digitointihankkeet vertailtaviksi”) on mielenkiintoinen esimerkki sen vuoksi, että hankkeen päätyttyä sen verkkosivuston ylläpito lakkasi, ja sen domain ekam.fi vuokrattiin (domaineja ei voi omistaa, vain vuokrata) edelleen hankolaiselle Eteläkärjen Automaalaamo Oy:lle, joka ei sekään ole ylläpitänyt sivujaan enää muutamaan vuoteen. Mikaelan Web-sivustosta on jäänyt muistoksi vain reilut 10 vuotta vanha kopio Internet Archiveen.

9 https://journal.fi/inf/index

10 https://journal.fi/signum/index

11 http://web.archive.org/web/*/http://www.helsinki.fi/arviointi/arviointiraportti.pdf 
Markku Kestin kirjoituksessa "RFID - lopun alkua viivakoodille" on kaksi eviittausta Library Journal -lehden artikkeleihin ProQuestin palvelussa. Vaikka niiden URL-osoitteet palvelussa ovat täysin muuttuneet, tekstit löytyvät edelleen. Toinen Signum-aineistosta esiin nouseva luotettava palvelu on Oulun yliopiston julkaisuarkisto; sinne tehdyt linkit toimivat yhä.

Vanhojen Signum-artikkeleiden elektroniset lähteet on siis edelleen mahdollista löytää, mutta useimmiten vain verkkoarkistoista. Merkittävien palvelujenkin sivujen osoite on voinut vaihtua, ja projektien tuottamien sivustojen ylläpito on lähes aina jäänyt retuperälle hankekauden päätyttyä. Käyttäjän kannalta kenties ongelmallisimpia tapauksia ovat ne, jossa linkki edelleen toimii, mutta vie käyttäjän muuttuneeseen tai täysin väärään sivustoon.

Informaatiotutkimus-lehdestä tarkastin vain vuonna 2009 julkaistujen artikkeleiden e-viitteet, koska viitteiden määrä on oleellisesti suurempi kuin Signumissa. Valitsin uudemman vuosikerran, koska noin 10 \% e-viitteiden URL-linkeistä lakkaa toimimasta jo ensimmäisen 12 kuukauden aikana (Klein ym., 2014). Ongelmia pitäisi siis näkyä jo varsin tuoreissakin teksteissä, eikä Informaatiotutkimus ole poikkeus. Tyypillinen tapaus on Kaisa Hypénin artikkeli "Kaunokirjallisuuden sisällöt ja kontekstit" vuodelta 2009; siinä on 16 e-viitettä, joista yhdeksän on joutunut joko linkkimädän tai sisältönyrjähdyksen uhriksi.

Hypén viittaa esimerkiksi yksittäiseen Arjen tietoyhteiskunta -hankkeen laatimaan sivuun, mutta projektin kaikki aineistot ovat kadonneet. Osoitteessa http: //arjentietoyhteiskunta.fi on ollut vuodesta 2016 lähtien rengasfirman mainos, ja Arjen tietoyhteiskunnan neuvottelukunnan sivut viettävät Internet Archivessa ennen aikojaan alkaneita eläkepäiviä. Sama kova kohtalo on ollut viittauksella Terve-Suomi-palveluun. Osoitteessa http://yso.fi ei enää ole Onki-palvelinta, mutta onneksi sentään Finto, jonka sisältö ei ole nyrjähtänyt Onkista kovin kauas.

Hypénin artikkelissa on myös kaksi viittausta KirjastoWikissä olleisiin sivuihin, mutta palvelu suljettiin kesällä 2015, ja sieltä pelastettiin uuteen KirjastoPropalveluun vain Kaukopalvelun käsikirja ja Erikoiskirjastojen ja tietopalvelujen verkoston sivut ${ }^{12}$. Palvelujen kuoppaaminen ei ole Internetissä mitenkään epätavallista, ja pahimmillaan nämä operaatiot tehdään ilman ennakkovaroitusta, jolloin asiakkaat joutuvat turvautumaan verkkoarkistoihin aineistojensa palauttamiseksi.

Hätkähdyttävintä on se, että Jyrki Nummen raporttia "Kirjallisuuspankki: suomalaisen kirjallisuuden digitaalinen kirjasto vuodelta 2008" ei enää löydy. Yllättävää ei niinkään ole se, että kyynärän mittainen URL $\mathrm{UR}^{13}$ ei toimi, vaan se, ettei raporttia löydy myöskään Fennicasta, googlaten eikä edes Internet Archivesta.

\footnotetext{
12 http://wiki.kirjastot.fi/

13 https://www.kansalliskirjasto.fi/attachments/5kSvIrHoj/5xYC3fd8g/Files/CurrentFile/ Kirjallisuuspankki-selvitys.pdf
} 
Jarmo Saartin folksonomioihin paneutuva artikkeli on myönteinen poikkeus: sen viisi e-viitettä ovat edelleen kunnossa. Suvi Järvenpään Bibliotek 2.0 på högskolebibliotek i Åbo -artikkelissa on vain pari kuollutta linkkiä, mutta niistä yksi on pysyvään tunnukseen perustuva HTTP URI (http://hdl. handle. net/1901/356). Handle-järjestelmän mukaan prefix on lakannut toimimasta eli Handle-resolveri on potkaissut tyhjää. Valitukset voi lähettää osoitteeseen University of North Carolina at Chapel Hill, School of Information and Library Science.

Saraleena Aarnitaipaleen artikkelissa "Maahanmuuttajien kokemuksia informaatiolukutaidosta kotoutumisen yhteydessä" on monia e-viitteitä, joista noin joka toisessa on ongelmia. Esimerkiksi osoitteessa http://www. newhorizons.org tarjotaan tätä kirjoitettaessa (kesäkuussa 2017) pikavippejä, eikä palvelimia http: //www. nclis . gov ja http://www. ajitpyati.ca enää löydy. Myös Isto Huvila on käyttänyt kosolti e-viitteitä artikkelissaan "Semantiska wiki som digitala arkivsystem". Sen lähteistä monet ovat tieteellisissä lehdissä julkaistuja artikkeleita, ja ne kaikki löytyvät edelleen, lukuun ottamatta Science Direct -palvelun kahta artikkelia.

Yleisesti ottaen vaikuttaa siltä, että kaupallisissa tieteellisissä julkaisuissa ilmestyneet aineistot ovat edelleen käytettävissä, vaikka palvelun ylläpitäjä ja osoite ovat muuttuneet. Julkishallinnon organisaatioiden tuottaman aineiston löytyvyys vaihtelee huomattavasti. Mutta jos julkaisijana on toiminut projekti, on syytä epäillä että aineistot ovat jääneet tuuliajolle, mahdollisesti jo pian projektin päättymisen jälkeen.

Vaikka tilannetta ei voi luonnehtia kriittiseksi, on kuitenkin syytä olla huolissaan siitä, että tässä pienessä selvityksessä analysoiduista artikkeleista lähes kaikki kärsivät viitemädästä. Eikä tilanne tulevaisuudessa ainakaan paremmaksi muutu, jos viitteitä tehdään edelleen samaan malliin. Siksi tarjoan lopuksi muutamia ohjeita, joilla viitteissä olevien linkkien elinkaarta saadaan varsin helposti pidennettyä.

\section{Suosituksia}

\section{Käytä pysyviä tunnuksia aina kun se on mahdollista.}

Pysyviä tunnuksia ovat Handle, DOI, URN ja ARK. Suomessa käytetään lähinnä kolmea ensin mainittua; DOI:ta käytetään tieteellisten artikkeleiden ja tutkimusdatan tunnisteena, Handlea sovelletaan julkaisuarkistoissa ja URN-järjestelmää hyödyntävät esim. Kansalliskirjasto ja useat julkishallinnon organisaatiot.

Julkaisulla voi olla useampikin PID; silloin pitää käyttää sitä, jonka kerrotaan olevan pysyvä osoite. Esimerkiksi KDK-hankkeen Oikeuksien hallintaan liittyvät metatiedot -selvityksen pysyvä osoite on URN (http://urn.fi/URN:NBN: fi-fe201702101528), mutta julkaisulla on myös DSpace-järjestelmän sisäinen Handle-tunnus (http:// 
WwW. doria.fi/handle/10024/133690) ja sen URL on http://www.doria.fi/bitstream/ handle/10024/133690/0ikeuksien\%20hallintaan\%201iittyva\%CC\%88t\%20metatiedot.pdf? sequence=2. Handlea ja URL-osoitetta ei saa käyttää viittaamiseen, koska ne muuttuvat jos selvitys joskus siirretään Doriasta johonkin muuhun julkaisuarkistoon tai jos Dorian tekninen alusta vaihtuu.

\section{Jos sivu on dynaaminen tai vaikuttaa lyhytikäiseltä, viittaa sivun arkistokopioon}

Internet Archiven tai muun verkkoarkiston käyttö on välttämätöntä, jos viitattu sivu on dynaaminen eli sen sisältö muuttuu, tai jos on todennäköistä tai varmaa, että sivu tulee katoamaan lähitulevaisuudessa. Eritoten projektisivustojen keskimääräinen elinkaari projektin päätyttyä voi olla kuin kanan lento. Ja kun projektin domain vapautuu, sen uudella vuokraajalla on harvoin jalot tarkoitusperät. Esimerkiksi tästä sopii vaikkapa http://www.kdk2011.fi, Kansallisen digitaalisen kirjaston hankkeen alkuperäinen verkko-osoite. Siellä on tarjottu jo muutaman vuoden ajan palveluita, joilla ei ole mitään tekemistä sen paremmin digitaalisen kuin muunkaan kirjaston kanssa.

Viittaus verkkoarkistoon voidaan tehdä tarpeen mukaan joko kaikki viitatun sivun arkistoidut kopiot kattavaksi tai yksittäiseen kopioon kohdistuvaksi. Kaikkiin sivuihin viitattaessa pitää olla riittävän varma, ettei sisältö nyrjähdä siten kuin esimerkiksi http://www.kdk2011.fi -sivustossa.

Kun alkuperäinen sivu verkossa on esimerkiksi http://www.hs.fi/, niin

Internet Archivessa kaikki haravoidut kopiot ovat osoitteessa: https: //web. archive. org/web/*/http://hs.fi

ja Helsingin Sanomat 2017-06-07 löytyy osoitteesta: https : //web.archive.org/ web/20170607030050/http://www.hs.fi/

Arkistoitua sivua käytettäessä on tietenkin varmistettava, että se vastaa sisällöllisesti alkuperäistä. Jos sivu koostuu useista tiedostoista, ne on voitu haravoida arkistoon eri aikoina siten, että lopputulos on harhaanjohtava.

Yksittäisen verkkoarkiston käyttö on tietysti riski - jos ja kun Internet Archiven toiminta päättyy, yllä olevat arkistolinkit eivät enää toimi. Varmuuden maksimoimiseksi voi käyttää kotimaiselle aineistolle Kansalliskirjaston verkkoarkistoa, jossa kaikki Helsingin Sanomien arkistoidut sivut löytyvät osoitteesta http: //verkkoarkisto. kansalliskirjasto.fi/wayback/*/hs.fi.

Kaikki verkkoarkistot käyttävät aineistojen haravointiin ja käyttöön asettamiseen Heritrix- ${ }^{14}$ ja OpenWayback ${ }^{15}$-sovelluksia, mutta haravointikäytänteiden ero-

\footnotetext{
14 https://webarchive.jira.com/wiki/display/Heritrix

15 http://netpreserve.org/openwayback
} 
jen vuoksi arkistojen sisällössä ja kattavuudessa voi olla merkittäviä eroja. Mementopalvelun ${ }^{16}$ avulla voi selvittää, löytyykö jostakin dokumentista arkistokopiota haluttuna ajankohtana (eli silloin, kun dokumenttiin on viitattu).

Esimerkiksi Valkoisen talon kotisivusta on runsaasti kopioita ennen ja jälkeen vallanvaihdon osoitteessa http://timetravel.mementoweb.org/list/20170119000000/ https://whitehouse.gov, mutta kaikki nämä sivut eivät välttämättä kerro koko totuutta siitä, miten sivu muuttui valitettavan vallanvaihdon myötä.

\section{Jos arkistokopiota ei ole, tee se itse}

Muutamat verkkoarkistot, kuten Internet Archive, mahdollistavat verkkosivujen käyttäjälähtöisen arkistoinnin. Tallensin tätä artikkelia kirjoittaessani Internet Archiven Save Page Now -toiminnolla Kopioston kotisivun ${ }^{17}$ Internet Archiveen, jossa 7. kesäkuuta 2017 klo 07.24.17 tehdyn kopion osoite on https://web.archive.org/ web/20170607072417/http://www.kopiosto.fi/fi_FI/. Tallennukseen meni kaikkineen vain muutama sekunti, mutta sen ansiosta kuka tahansa voi viitata tähän versioon Kopioston kotisivusta, ja luottaa siihen että linkki toimii pitkään. Mutta mitään takeita siitä, että arkistoituun kotisivuun tallennetut linkit Kopioston muille sivuille toimivat $\mathrm{OK}$; ei ole.

Verkkoarkistoihin ei ole mahdollista arkistoida likikään kaikkea aineistoa. Monien sosiaalisen median palveluiden osalta olemme riippuvaisia kyseisistä palveluista, vaikka poikkeuksiakin on - Twitter on lahjoittanut kaikki twiitit Kongressin kirjastolle ${ }^{18}$. Valitettavasti kirjaston Twitter-arkisto on resurssipulan vuoksi edelleen avaamatta $^{19}$, mikä on hyvä osoitus siitä, millaisia haasteita Internetin arkistoiminen kansalliskirjastoille asettaa.

Tämän artikkelin alaviitteet ovat esittämieni periaatteiden vastaisia tarkoituksella: lukija voi tarkistaa muutaman vuoden kuluttua, vieläkö linkit toimivat. Jos eivät, käyttämäni aineistot voi yrittää löytää Internet-Archiven tai Mementon avulla.

\section{Viittauskäytänteiden standardoinnista}

Lähde- ja tekstiviitteiden laatimisesta on olemassa sekä kansainvälinen ISO-standardi ISO 690:2010 että sen suomenkielinen versio, SFS 5989 vuodelta 2012. SFS-standardiin

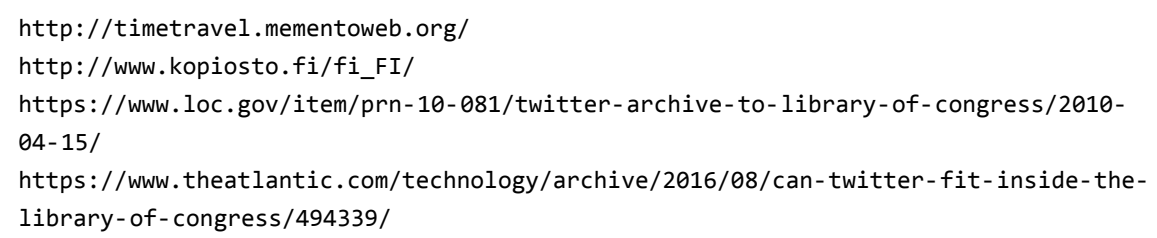


lisättiin luku data-aineistoihin viittaamisesta, ja e-viittaamista koskeva ohjeistus ajantasaistettiin - vanhentuneet esimerkit päivitettiin, ja ohjeissa korostettiin pysyvien tunnusten soveltamisen tärkeyttä. Kumpikaan standardi ei esitä yhtä ainoata viittaamisen mallia, vaan tarjoaa malliratkaisuja ja hyviä käytänteitä. E-viittaamisessa suositeltavien käytänteiden tärkeys korostuu.

Suomi teki vuonna 2016 ehdotuksen ISO 690 -standardin uusimisesta, koska se oli meidän mielestämme pahoin vanhentunut e-viittaamisen osalta. Ehdotukseen liitettiin luonnos uudeksi standardiksi, johon sisältyivät kaikki SFS 5989:n uudet piirteet sekä ohjeet sosiaaliseen mediaan kuten twiitteihin, blogisivuihin ja Facebook-aineistoihin viittaamisesta. Esitys standardin uudistamisesta hyväksyttiin "kaikin tuomariäänin" ja Tietohuoltokomitea valmistelee parhaillaan seuraavaa standardiluonnosta, jossa otetaan huomioon ensimmäisellä äänestyskierroksella saatu palaute. Luonnokseen lisätään myös ohjeistus dynaamisiin data-aineistoihin viittaamisesta.

Uutta ISO-standardia joudutaan odottamaan vielä 1.5-2 vuotta, koska seuraavaksi äänestetään ns. Committee Draft -versiosta, minkä jälkeen tarvitaan vielä ainakin Draft International Standard -äänestys. Jos DIS-vaiheessa ei tule ei-ääniä (toistaiseksi olemme selvinneet ilman niitä), standardi on valmis julkaistavaksi. Tietohuoltokomitean tavoitteena on, että suomenkielinen versio standardista julkaistaan joko samaan aikaan ISO-standardin kanssa, tai mahdollisimman pian sen jälkeen.

\section{Lähteet}

Heinisuo, R., \& Ekholm, K. (1997). Elektronisen viittaamisen opas. Jyväskylän yliopiston kirjasto. Jones, S., Van de Sompel, H., Shankar, H., Klein, M., Tobin, R., \& Grover, C. (2016). Correction: Scholarly Context Adrift: Three out of Four URI References Lead to Changed Content. PLoS ONE, 12(1). https://oadoi.org/10.1371/journal. pone. 0167475

Jyväskylän yliopiston kirjasto. (2017). Merkitse oikein lähteet ja viittaukset. Kirjastotuutori. https: //koppa.jyu.fi/avoimet/kirjasto/kirjastotuutori/lahteet-hallintaan/lahteet-viittaukset

Klein, M., Van de Sompel, H., Sanderson, R., Shankar, H., Balakireva, L., Zhou, K., \& Tobin, R. (2014). Scholarly Context Not Found: One in Five Articles Suffers from Reference Rot. PLoS ONE, 9(12). https://oadoi.org/10.1371/journal. pone. 0115253

Öhman, C. (1961). August Strindberg and the Origin of the Scenic Expressionism (s. 235). Helsingfors.

Van de Sompel, H., Klein, M., \& Jones, S. (2016). Persistent URIs Must Be Used To Be Persistent. https://arxiv.org/abs/1602.09102 